\title{
PENGARUH PENGGUNAAN PERPUSTAKAAN SEKOLAH TERHADAP MINAT BELAJAR PESERTA DIDIK KELAS VIII DI SIMPN 3 MINASATE'NE PANGKEP
}

\author{
Selfa Afia ${ }^{1}$,Syahruddin Usman ${ }^{2}$,Abd. Syukur Abu Bakar ${ }^{3}$ \\ Universitas Islam Negeri Alauddin Makassar
}

\begin{abstract}
This study aims to determine the use of the school library at SMPN 3 Minasate'ne Pangkep, to determine the learning interest of students at SMPN 3 Minasate'ne Pangkep and to analyze the effect of using the school library on the learning interest of students at SMPN 3 Minasate'ne Pangkep. This research is a quantitative research with ex post facto method. Based on the results of the study, it can be concluded that: 1) the use of the school library at SMPN 3 Minasate'ne Pangkep is in the medium category with a percentage of $75 \%$ while the learning interest of students at SMPN 3 Minasate'ne Pangkep is also in the medium category with a percentage of $67.5 \%$. From the calculation results obtained (tcount) $=2.91$ while $($ ttable $)=1.684$ for a significance level of 5\%. Because tcount is greater than ttable, it can be concluded that $\mathrm{HO}$ is rejected and $\mathrm{HI}$ is accepted. The implication of this research is for students at SMPN 3 Minasate'ne Pangkep to use the school library more in learning. For teachers to be able to use the school library as a learning tool so that students' interest in learning is increasing. For schools to be able to become input and improve the use of the library by further complementing subject books or providing other reading materials to attract more students' interest. For future researchers, it can be used as reference material in conducting research on the use of school libraries and interest in learning.
\end{abstract}

Keywords: Use of the school library, interest in learning

\section{PENDAHULUAN}

Pendidikan merupakan wahana atau kendaraan untuk mewujudkan suatu proses atau suasana belajar yang aktif sesuai dengan maklumat yang tercantum dalam UndangUndang Nomor 20 Tahun 2003 tentang Sistem Pendidikan Nasional, disebutkan bahwa:

Pendidikan adalah usaha sadar dan terencana untuk mewujudkan suasana belajar dan proses pembelajaran agar peserta didik secara aktif mengembangkan potensi dirinya untuk memiliki kekuatan spiritual keagamaan, pengendalian diri, kepribadian, kecerdasan akhlak mulia, serta keterampilan yang diperlukan dirinya, masyarakat, bangsa dan negara. ${ }^{1}$

Agar pendidikan dapat memenuhi sasaran yang telah direncanakan, maka dari itu pendidikan harus dapat terlaksana sebaik mungkin sehingga mendapatkan hasil yang maksimal. Dengan demikian, pemerintah harus mengoptimalkan segala sarana dan prasarana yang dapat menunjang keberlangsungan proses pembelajaran seperti media

\footnotetext{
${ }^{1}$ Abdul Rahman Shaleh, Pendidikan Agama dan Pembangunan Watak Bangsa (Jakarta: Rajagrafindo Persada, 2005), h. 37.
} 
pembelajaran, gedung atau ruang perpustakaan, keterampilan latihan praktek dan lainlain.

Sarana merupakan alat-alat yang dipergunakan peserta didik dalam membantu proses belajarnya seperti ruangan, alat-alat pembelajaran, penerangan serta suasana tempat belajar. Fasilitas belajar mempunyai pengaruh sangat besar terhadap minat belajar peserta didik. Semakin lengkap fasilitas pembelajaran yang tersedia maka peserta didik dapat belajar lebih baik ${ }^{2}$. Salah satu sarana penting yang harus diperhatikan adalah pembangunan ruang perpustakaan untuk keberlangsungan pembelajaran. Dalam UndangUndang Nomor 24 tahun 2014 pada Bab I tentang perpustakaan pasal 1 disebutkan bahwa:

Perpustakaan adalah institut pengelola koleksi karya tulis, karya cetak, dan/atau karya rekam secara propesional dengan sistem yang baku guna memenuhi kebutuhan-kebutuhan pendidikan, penelitian, pelestarian, infromasi, dan rekreasi para pemustaka. ${ }^{3}$

Dari pengertian di atas maka dapat digambarkan bahwa perpustakaan merupakan suatu gedung untuk mengelola koleksi-koleksi bahan pustaka untuk memenuhi kebutuhan pendidikan, penelitian dan informasi. Maka dengan adanya perpustakaan diharapkan kepada peserta didik untuk dapat memanfaatkannya dengan baik seperti mengunjungi perpustakaan untuk membaca buku, meminjam buku atau mencari informasi lainnya guna untuk menambah minat belajar peserta didik.

Peserta didik yang memiliki minat besar akan bersungguh-sungguh untuk bisa mencapai tujuan yang dikehendakinya. Minat dapat diartian sebagai ketertarikan peserta didik akan pembelajaran. Minat bisa timbul karena adanya dorongan dari diri sendiri ataupun dari keluarga dan lingkungan sosial. Dalam kegiatan proses belajar mengajar, minat berperan sebagai kekuatan yang dapat mendorong peserta didik untuk belajar. Minat belajar peserta didik sangat mempengaruhi prestasi peserta didik, bukan hanya bergantung pada keinginan hati peserta didik untuk belajar. Berbeda halnya dengan peserta didik yang hanya menerima pembelajaran, tergerak mau belajar tanpa ada minat dalam dirinya. ${ }^{4}$

Diharapkan dengan adanya perpustakaan sekolah dapat menambah atau meningkatkan minat belajar peserta didik terkhusus pada mata pelajaran pendidikan Agama Islam sehingga proses pembelajaran dapat terarah dan terlaksana secara maksimal. Serta program peningkatan mutu pembelajaran dapat tercapai bila proses pembelajaran di kelas berlangsung dengan baik, berdaya guna dan berhasil guna.

\footnotetext{
${ }^{2}$ Aswan Zain, Strategi Belajar Mengajar (Jakarta: Rineka Cipta, 2008), h. 209.

${ }^{3}$ Peraturan Pemerintah Republik Indonesia Nomor 24 Tahun 2014 Tentang Pelaksanaan UndangUndang Nomr 43 Tahun 2007 tentang Perpustakaan (Jakarta, 2015), h. 2.

${ }^{4}$ Rubianti, Pengaruh Kemandiria, Fasilitas dan minat Belajar trhadap Prestasi Belajar Sosiologi, Jurnal Ideguru 2, Nomor 1 (Mei, 2017): h. 13.
} 
Dari observasi awal yang peneliti lakukan di SMPN 3 Minasate'ne Pangkep pada tanggal 11 Januari 2020, peneliti menilai dan melihat banyak peserta didik yang lebih suka nongkrong di kantin daripada mengunjungi perpustakaan, masih ada peserta didik yang bermain pada saat mengerjakan tugas di perpustakaan, peserta didik lebih suka membuang-buang waktu jam istirahatnya di kelas dibandingkan di perpustakaan dan peneliti rasa pembangunan perpustakaan yang terbilang kurang memadai juga menyebabkan peserta didik kurang tertarik untuk mengunjungi perpustakaan.

Berdasarkan uraian di atas, maka peneliti tertarik untuk melakukan penelitian tentang "Pengaruh Penggunaan Perpustakaan Sekolah terhadap Minat Belajar Peserta Didik di SMPN 3 Minasate'ne Pangkep" Berdasarkan latar belakang yang telah diuraikan, maka rumusan masalah yang diangkat dalam penelitian ini adalah:

1. Bagaimana penggunaan perpustakaan sekolah di SMPN 3 Minasate'ne Pangkep?

2. Bagaimana minat belajar peserta didik di SMPN 3 Minasate'ne Pangkep?

3. Apakah penggunaan perpustakaan sekolah berpengaruh terhadap minat belajar peserta didik di SMPN 3 Minasate'ne Pangkep?

\section{METODOLOGI PENELITIAN}

Jenis penelitian yang digunakan pada penelitian ini adalah penelitian kuantitatif. Penelitian kuantitatif ini menggunakan rancangan ex post facto. Penelitan kuantitatif rancangan ex post facto ini bertujuan untuk mencari kembali dan jika dimungkinkan mencari tahu apa yang menyebabkan faktor terjadinya sesuatu. Pendekatan penelitian yang digunakan dalam penelitian ini adalah pendekatan pendidikan dan pendekatan psikologi. penulis menggunakan pendekatan psikologi karena penelitian ini mengamati tentang perilaku peserta didik di sekolah yang ditunjukkan pada aktivitas sehari-harinya ${ }^{5}$. Dalam hal ini peneliti berusaha meneliti tentang penelitian pengaruh penggunaan perpustakaan sekolah terhadap minat belajar peserta didik di SMPN 3 Minasate'ne Pangkep.

\section{TINJAUAN TEORETIS}

\section{A. Perpustakaan sekolah}

\section{Pengertian perpustakaan sekolah}

Kata perpustakaan dalam bahasa Indonesia berasal dari kata dasar 'pustaka' yang berarti kitab, buku. Dalam bahasa Inggris disebut library yang berarti room or building for acollection of books kept there for reading, ruang atau bangunan tempat menyimpan koleksi buku-buku untuk keperluan baca. Dalam bahasa asing disebut bibliotheca

${ }^{5}$ Suharsimi Arikunto, Prosedur Penelitian Suatu pendekatan Praktik (Jakarta: Rineka Cipta, 2006), h. 12. 
(Spanyol dan Portugis) yang berasal dari kata biblia (Yunani) yang berarti buku, kitab. Dalam bahasa Arab disebut Al-maktabah, berasal dari akar kata kitab yang juga berarti buku. $^{6}$

Dalam Rancangan Undang-Undang (RUU) perpustakaan pada Bab 1 Pasal 1 menyatakan bahwa:

Perpustakaan merupakan sebuah institusi yang mengumpulkan pengetahuan tercetak dan terekam, mengelolanya dengan cara khusus untuk memenuhi kebutuhan intelektualitas para penggunanya melalui beragam cara interaksi pengetahuan. ${ }^{7}$

Berdasarkan beberapa pengertian di atas, maka dapat disimpulkan bahwa perpustakaan adalah suatu lembaga tertentu yang menyimpan koleksi dan bahan-bahan perpustakaan secara teratur serta mengelolanya dengan cara khusus sebagai sumber informasi dan dapat digunakan oleh pembaca dan penggunanya. Tersimpan dalam bentuk buku disusun berdasarkan tata susunan tertentu yang dapat dibaca, tetapi bukan untuk diperjual belikan.

Perpustakaan bukanlah suatu hal yang baru di lapisan masyarakat. Keberadaan perpustakaan telah ada di mana-mana, seperti di sekolah, baik sekolah dasar maupun sekolah menengah dan baik sekolah umum maupun sekolah kejuruan. Selain di sekolah perpustakaan juga telah ada di kantor dan juga perpustakaan umum telah ada di tingkat kabupaten sampai dengan tingkat desa. ${ }^{8}$

Perpustakaan sekolah adalah perpustakaan yang berada di lingkungan sekolah. Diadakannya perpustakaan sekolah adalah untuk memenuhi kebutuhan informasi bagi masyarakat di lingkungan sekolah yang bersangkutan, khususnya para peserta didik dan pendidik. Perpustakaan berperan sebagai media dan sarana untuk menunjang kegiatan proses belajar mengajar di tingkat sekolah. Oleh karena itu perpustakaan merupakan bagian integral dari program penyelenggaraan pendidikan tingkat sekolah. ${ }^{9}$ Perpustakaan sekolah sebagai salah satu sarana pendidikan penunjang kegiatan belajar peserta didik yang memegang peranan sangat penting dalam memacu tercapainya tujuan pendidikan di sekolah. Menurut Undang-Undang Sistem Pendidikan Nasional perpustakaan merupakan salah satu sarana belajar di sekolah guna terselenggaranya tugas para pendidik dan peserta didik dengan baik. ${ }^{10}$

${ }^{6}$ Agus Rifal, Perpustakaan Islam (Depok: Rajagrafindo Persada, 2014), h. 5.

${ }^{7}$ Priyono Darmanto, Manajemen Perpustakaan (Jakarta: Bumi Aksara, 2018), h.1.

${ }^{8}$ Ibrahim Bafadal, Pengelolaan Perpustakaan Sekolah (Cet. X; Jakarta: Bumi Aksara, 2015), h. 1.

${ }^{9}$ Yusuf M, Pedoman Penyelenggaraan Perpustakaan Sekolah (Cet. IV; Jakarta: Fajar Interpratama Mandiri, 2013), .h. 1.

${ }^{10}$ Safrudin Aziz, Perpustakaan Ramah Difabel: Mengelolah Layanan Informasi bagi Pemustakaan Difabel, h. 24. 
Dari berbagai defenisi di atas, maka penulis dapat simpulkan bahwa perpustakaan sekolah merupakan perpustakaan yang didirikan di sekolah, berada pada lingkungan sekolah yang bertugas menyediakan informasi dan gagasan yang sangat diperlukan sebagai informasi yang berbasis ilmu.

\section{Manfaat perpustakaan sekolah}

Perpustakaan merupakan upaya untuk memelihara, meningkatkan efisensi serta efektifitas proses belajar mengajar. Perpustakaan yang telah terorganisir dengan baik dan sistematis maka secara langsung maupun tidak langsung memberikan kemudahan dalam proses belajar mengajar di sekolah. Hal ini dikarenakan telah majunya pendidikan yang dirasakan serta tidak bisa dipisahkan dari permasalahan penyediaan fasilitas dan sarana prasarana pendidikan. ${ }^{11}$

Mengenai manfaat perpustakaan sekolah secara terinci yang dikemukakan oleh Ibrahim Bafadal adalah sebagai berikut:

a. Perpustakaan sekolah mampu menimbulkan kecintaan peserta didik terhadap membaca.

b. Memperkaya pengalaman belajar peserta didik.

c. Mempercepat penguasaan teknik membaca.

d. Membantu perkembangan kecakapan membaca.

e. Menentukan kebiasaan belajar sendiri.

f. Melatih peserta didik ke arah tanggung jawab.

g. Memperlancar peserta didik dalam menyelesaikan tugas-tugas sekolah. ${ }^{12}$

Pada kenyataanya perpustakaan sekolah akan tampak bermanfaat apabila benarbenar memperlancar pencapaian tujuan proses pembelajaran di sekolah. Manfaat tersebut bukan hanya dilihat dari indikasi prestasi peserta didik akan tetapi jauh dari itu, misalnya peserta didik mampu mencari, menemukan, menyaring serta menilai informasi. Peserta didik terbiasa belajar mandiri, terlatih ke arah tanggung jawab dan mampu untuk mengikuti perkembangan ilmu pengetahuan dan teknologi saat ini.

\footnotetext{
${ }^{11}$ Alias Mangnga, "Peranan Perpustakaan Sekolah terhadap Proses Belajar Mengajar di Sekolah", Jupiter 14, no.1 (Maret 2015): h. 39.

${ }^{12}$ Ibrahim Bafadal, Pengelolaan Perpustakaan Sekolah, h. 5.
} 


\section{B. Minat Belajar}

\section{Pengertian Minat Belajar}

Minat adalah rasa lebih suka, ketertarikan terhadap suatu hal atau kegiatan tanpa ada seorangpun yang menyuruh. Minat pada dasarnya merupakan penerimaan akan suatu hubungan antara diri sendiri dengan sesuatu yang di luar diri. Semakin kuat atau dekat hubungan tersebut maka semakin besar minatnya. Crow and Crow berpendapat bahwa minat berhubungan dengan gaya gerak yang dapat mendorong seseorang untuk berurusan atau menghadapi seseorang, kegiatan, benda dan pengalaman yang dirangsang oleh kegiatan itu sendiri. ${ }^{13}$ Minat belajar adalah suatu gejala psikologis yang menyebabkan pemusatan reaksi atau perhatian terhadap suatu objek benda tertentu maupun situasi tertentu. Menurut Dyimyati, minat belajar adalah sebagai kekuatan pendorong yang membuat seseorang memberikan perhatian kepada orang dalam situasi atau aktivitas tertentu. Minat juga sebagai akibat pengalaman efektif yang distimulur dengan hadirnya seseorang, suatu objek atau karena berpartisipasinya dalam suatu kegiatan. ${ }^{14}$

Maka dapat disimpulkan bahwa minat belajar adalah sebagai kecenderungan peserta didik terhadap objek atau suatu kegiatan, baik pelajaran maupun kegiatan lain di sekolah. Sesuatu yang digemari disertai dengan perasaan senang dan adanya perhatian yang didukung dengan keaktifan dalam pelaksanaannya. Pada dasarnya seorang peserta didik pasti memiliki kecenderungan untuk menyukai satu atau beberapa mata pelajaran serta kegiatan sekolah lainnya.

\section{Peranan dan Fungsi Minat Belajar}

Minat memiliki peranan penting dalam kehidupan manusia dan dampak yang besar atas sikap dan perilaku. Minat menjadi motivasi yang kuat untuk belajar. William Amstrong menyatakan bahwa konsentrasi tidak akan ada apabila tidak memiliki minat yang memadai dan seseorang tidak akan melakukan kegiatan apapun apabila tidak memiliki minat.

Peranan minat pada proses belajar mengajar adalah untuk pemusatan pikiran serta menghadirkan kegembiraan dalam usaha belajar seperti adanya kegairahan, memperbesar kemampuan daya belajar, membantu untuk tidak melupakan apa yang telah dipelajari, belajar penuh dengan semangat, membuat rasa kepuasan dan kesenangan tersendiri. ${ }^{15}$

Fungsi minat terhadap pembelajaran lebih mengarah sebagai motivating force yaitu kekuatan untuk mendorong peserta didik dalam belajar. Peserta didik yang berminat pada pembelajaran akan tampak terdorong terus menerus untuk belajar. Lain halnya dengan peserta didik yang sikapnya hanya menerima pembelajaran. Mereka hanya tergerak untuk

\footnotetext{
${ }^{13}$ Djali, Psikologi Pendidikan (Cet. X; Jakarta: Bumi Aksara, 2017), h. 121.

${ }^{14}$ Jumaidi Nur, "Pengaruh Sarana Belajar Terhadap Minat Belajar Siswa Kelas VII SMK Negeri 4 Tenggarong", Jurnal Cemerlang 3, no. 1 (Juni 2015): h. 3.

${ }^{15}$ Sutrisno, Meningkatkan Minat dan Hasil Belajar TIK (Malang: Ahlimedia, 2021), h. 11.
} 
ingin belajar akan tetapi sulit untuk terus tekun karena tidak adanya dorongan dalam dirinya. Oleh karena itu, untuk mendapatkan hasil yang maksimal dalam pembelajaran maka peserta didik harus mempunyai minat akan pembelajaran tersebut sehingga dapat mendorong peserta didik untuk terus belajar. ${ }^{16}$

Dari penjelasan di atas maka dapat disimpulkan bahwa peranan minat memiliki dampak yang besar atas sikap dan perilaku manusia. Sedangkan fungsi minat belajar lebih mengarah sebagai kekuatan untuk mendorong peserta didik dalam belajar sehingga mendapatkan hasil yang maksimal.

\section{Faktor yang Mempengaruhi Minat Belajar}

Minat belajar peserta didik tidak selalu stabil, melainkan berubah-ubah. Oleh sebab itu perlu diarahkan serta dikembangkan kepada suatu pilihan yang telah ditentukan melalu faktor yang mempengaruhi minat belajar itu sendiri. Secara garis besar faktor yang mempengaruhi minat belajar peserta didik dibagi ke dalam dua kelompok, yaitu faktor internal atau faktor yang berasal dari dalam diri peserta didik dan faktor eksternal atau faktor yang berasal dari luar diri peserta didik.

a. Faktor Internal

Faktor internal adalah sesuatu yang membuat peserta didik berminat untuk belajar yang berasal dari dalam diri peserta didik itu sendiri Faktor internal tersebut antara lain yaitu:

1) Perhatian dalam belajar, yaitu pemusatan atau konsentrasi terhadap seluruh aktivitas peserta didik yang ditunjukan kepada sesuatu objek.

2) Kebutuhan, yaitu keadaan dalam diri peserta didik yang mendorong untuk melakukan suatu aktivitas tertentu guna untuk mencapai suatu tujuan.

3) Keingintahuan, yaitu sikap, perasaan atau dorongan yang kuat untuk mencari informasi dan mengetahui sesuatu.

4) Motivasi, yaitu perubahan energi dalam diri peserta didik yang ditandai dengan timbulnya perasaan atau reaksi untuk mencapai tujuan. ${ }^{17}$

\section{b. Faktor Eksternal}

Faktor ekternal merupakan sesuatu yang membuat peserta didik berminat dalam pembelajaran yang datang dari luar diri peserta didik itu sendiri. Faktor eksternal tersebut antara lain yaitu:

\footnotetext{
${ }^{16}$ Edy Syahputra, Snowball Throwing Tingkatkan Minat dan Hasil Belajar (Sukabumi: Haura Publishing, 2020), h. 20.

${ }^{17}$ Edy Syahputra, Snowball Throwing Tingkatkan Minat dan Hasil Belajar, h. 21.
} 
1) Dukungan Keluarga

Keluarga memiliki peran penting dalam pembentukan tingkah laku, sifat dan corak peserta didik. Dukungan keluarga adalah sikap pemberian bantuan atau perhatian. Kenyataanya dukungan yang paling besar berasal dari orangtua. Diartikan sebagai sikap atau pemberian rasa kasih sayang kepada peserta didik.

2) Lingkungan Sekolah

Lingkungan sekolah memiliki pengaruh yang besar terhadap minat belajar peserta didik. Apabila peserta didik tidak dapat menyesuaikan dengan lingkungan sekolahnya, maka akan berakibat pada kurangnya minat peserta didik terhadap pembelajaran. ${ }^{18}$

Kurt Singer menyampaikan beberapa faktor yang dapat menimbulkan minat terhadap pembelajaran, yaitu sebagai berikut:

a) Pembelajaran akan menarik minat peserta didik apabila ada hubungannya dengan kehidupan nyata.

b) Bantuan yang diberikan guru terhadap peserta didiknya dapat membuat tujuan peserta didik tercapai.

c) Adanya kesempatan yang diberikan pendidik kepada peserta didik untuk memiliki peran aktif dalam proses pembelajaran.

d) Sikap pendidik dalam usaha untuk meningkatkan minat belajar peserta didik harus diperhatikan. Sikap seorang pendidik yang tidak disukai oleh peserta didik tentunya akan menyebabkan kurangnya minat dan perhatian peserta didik terhadap mata pelajaran yang diajarkan.

Dari penjelasan tersebut, maka penulis dapat simpulkan bahwa ada dua faktor yang dapat mempengaruhi minat belajar yaitu faktor internal dan eksternal. Faktor internal atau faktor dari dalam diri peserta didik terbagi menjadi beberapa bagian antara lain adalah perhatian dalam belajar, kebutuhan, keingintahuan, dan motivasi. Sedangkan faktor eksternal atau faktor dari luar diri peserta didik terbagi menjadi dua yaitu lingkungan keluarga dan lingkungan di sekolah.

\footnotetext{
${ }^{18}$ Prapanca, Minat Siswa Kelas IX terhadap Mata Pelajaran Tata Boga di SMA Negeri 1 Temon, Skripsi (Yogyakarta: Fakultas Teknik Universitas Negeri Yogyakarta, 2012), h. 9.

${ }^{18}$ Darmadi, Pengembangan Model Metode Pembelajaran dalam Dinamika Belajar Siswa, (Yogyakarta: Budi Utama, 2017), h. 313.
} 


\section{HASIL PENELITIAN DAN PEMBAHASAN}

\section{A. Pembahasan}

1. Deskripsi Penggunaan Perpustakaan Sekolah Peserta Didik Kelas VIII SMPN 3 Minasate'ne Pangkep

Perpustakaan merupakan sarana yang digunakan untuk pembelajaran peserta didik secara mandiri. Selain itu perpustakaan juga berfungsi untuk lebih menumbuhkan minat belajar peserta didik dan memberikan kemudahan dalam poses belajar di sekolah. Dimana perpustakaan sekolah akan tampak brmanfaat apabila benar-benar dapat memperlancar pencapaian tujuan proses pemebelajaran di sekolah. Adapun indikator penggunaan perpustakaan sekolah yaitu berkunjung ke perpustakaan, meminjam koleksi buku di perpustakaan, membaca buku di perpustakaan, mengerjakan tugas di perpustakaan, kegiatan belajar dilakukan di perpustakaan dan penggunaan bahan pustaka sebagai sumber belajar. Dimana indikotor yang ada dikembangkan dan disusun dalam bentuk pernyataan-pernyataan instrumen sehingga diperoleh data yang terdapat pada table di bawah ini.

\section{Tabel 4.1}

\section{Statistik Deskriptif Penggunaan Perpustakaan Sekolah Peserta Didik kelas VIII SMPN 3 Minasate'ne Pangkep}

\begin{tabular}{|l|l|}
\hline Jumlah Sampel & 40 \\
\hline Skor Maksimum & 62 \\
\hline Skor Minimum & 25 \\
\hline Mean & 47,38 \\
\hline Standar Deviasi & 8,32 \\
\hline Range & 37 \\
\hline
\end{tabular}

Berdasarkan tabel di atas, maka hasil analisis desktiktif nilai angket pengunaan perpustakaan sekolah dengan menggunakan SPSS 23, maka dapat dketahui nilai range adalah 37 , nilai minimum adalah 25 , nilai maximum adalah 62 , nilai mean adalah 47,38 dan nilai standar deviasi adalah 8,32. Selanjutnya analisis kategorisasi penggunaan perpustakaan sekolah peserta didik kelas VIII SMPN 3 Minasate'ne Pangkep disajikan pada tabel di bawah ini: 
Tabel 4.2

Kategorisasi Penggunaan Perpustakaan Sekolah Peserta Didik Kelas VIII SMPN 3 Minasate'ne Pangkep

\begin{tabular}{|c|l|l|c|c|}
\hline No. & Katogori & Interval & Frekuensi & Presentase \\
\hline 1. & Rendah & $\mathrm{X}<39$ & 3 & $7,5 \%$ \\
\hline 2. & Sedang & $39 \leq \mathrm{X}<56$ & 30 & $75 \%$ \\
\hline 3. & Tinggi & $\mathrm{X} \geq 56$ & 7 & $17,5 \%$ \\
\hline Jumlah & & 40 & $100 \%$ \\
\hline
\end{tabular}

Dari tabel di atas dalam kategorisasi penggunaan perpustakaan sekolah kelas VIII di SMPN 3 Minasate'ne Pangkep terdapat 3 orang responden pada kategori rendah dengan presentase 7,5\%,30 orang responden pada kategori sedang dengan persentase $75 \%$ dan 7 orang responden pada kategori sedang dengan persentase $17,5 \%$.

\section{Deskripsi Minat Belajar Peserta Didik Kelas VIII SMPN 3 Minasate'ne Pangkep}

Minat belajar adalah rasa suka, perhatian, serta ketertarikan peserta didik terhadap proses pembelajaran yang mereka jalani dan kemudian ditunjukkan melalui keantusiasan, partisipasi serta keaktifan dalam mengikuti proses pembelajaran yang mereka jalani. Indikator dari minat belajar yang diambil peneliti yaitu perhatian, ketertarikan, rasa senang, keterlibatan, partisipasi dalam aktifitas belajar dan adanya kesadaran untuk belajar tanpa disuruh.

Berdasarkan hasil penelitian yang dilakukan di SMPN 3 Minasate'ne Pangkep peserta didik kelas VIII dengan jumlah 40 orang. Maka peneliti mengumpulkan data melalui angket minat belajar yang yang diisi oleh responden/peserta didik dan kemudian diberikan skor dengan masing-masing soal disajikan di bawah ini sebagai berikut.

Dari perolehan skor di atas, maka berikut ini adalah tabel hasil analisis deskriktif minat belajar peserta didik kelas VIII SMPN 3 Minasate'ne Pangkep yang dengan jumlah sampel 40 responden/peserta didik yaitu sebagai berikut:

Tabel 4.3

Statistik Deskriptif Minat Belajar Peserta Didik Kelas VIII SMPN 3 Minasate'ne Pangkep

\begin{tabular}{|l|l|}
\hline Jumlah Sampel & 40 \\
\hline Skor Maksimum & 46 \\
\hline
\end{tabular}




\begin{tabular}{|l|l|}
\hline Skor Minimum & 20 \\
\hline Mean & 35,93 \\
\hline Standar Deviasi & 5.65 \\
\hline Range & 26 \\
\hline
\end{tabular}

Dari tabel di atas, maka hasil analisis desktiktif nilai angket minat belajar peserta didik. Maka dapat dketahui nilai range adalah 26, nilai minimum adalah 20, nilai maximum adalah 46, nilai mean adalah 35,93, nilai standar deviasi adalah 5,650 dan nilai variance sebesar 31,91. Selanjutnya analisis kategorisasi minat belajar peserta didik kelas VIII SMPN 3 Minasate'ne Pangkep disajikan pada tabel di bawah ini:

Tabel 4.4

Kategorisasi Minat Belajar Peserta Didik Kelas VIII SMPN 3 Minasate'ne Pangkep

\begin{tabular}{|c|l|c|c|c|}
\hline No. & Katogori & Interval & Frekuensi & Presentase \\
\hline 1. & Rendah & $\mathrm{X}<30$ & 3 & $7,5 \%$ \\
\hline 2. & Sedang & $30 \leq \mathrm{X}<41$ & 27 & $67,5 \%$ \\
\hline 3. & Tinggi & $\mathrm{X} \geq 41$ & 10 & $25 \%$ \\
\hline Jumlah & & 40 & $100 \%$ \\
\hline
\end{tabular}

Dari tabel di atas pada kategorisasi minat belajar peserta didik terdapat 3 orang responden pada kategori rendah dengan presentase 7,5\%, 27 orang responden pada kategori sedang dengan persentase $67,5 \%$ dan 10 orang responden pada kategori tinggi dengan persentase $25 \%$.

\section{Analisis Pengaruh Penggunaan Perpustakaan Sekolah terhadap Minat Belajar}

\section{Peserta didik Kelas VIII di SMPN 3 Minasate'ne Pangkep}

Pada tahap ini akan digunakan analisis inferensial untuk menjawab rumusan masalah selanjutnya atau rumusan masalah ketiga yaitu ada atau tidak pengaruh penggunaan perpustakaan sekolah terhadap minat belajar peserta didik kelas VIII di SMPN 3 Minasate'ne Pangkep. Pengolahan data penggunaan perpustakaan sekolah dan minat belajar dilakukan untuk mengetahui seberapa besar kecilnya sumbangan variabel $\mathrm{X}$ (penggunaan perpustakaan sekolah) terhadap variabel Y (minat belajar). 


\section{a. Uji Normalitas}

Uji normalitas digunakan untuk mengetahui apakah penelitian penggunaan perpustakaan sekolah terhadap minat belajar berdistribusi secara normal atau tidak.

Dalam melakukan uji ini, digunakan pengujian normalitas Kolmogorov Smirnov, dihitung menggunakan aplikasi SPSS versi 23 yang menggunakan taraf signifikansi $\alpha$ $=0,05$.

- Jika nilai Sig. > 0,05 maka data berdistribusi normal.

- Jika nilai Sig. < 0,05 maka data tidak berdistribusi normal.

\section{Tabel 4.5}

Uji Normalitas Teknik Kolmogorov Smirnov

\begin{tabular}{|l|l|l|l|}
\hline Variabel & K-Smirnov & Sig. & Keterangan \\
\hline X terhadap Y & 0.200 & 0.05 & Normal \\
\hline
\end{tabular}

Pada tabel 4.9 hasil output SPSS di atas, pengujian normalitas dilakukan pada pengaruh penggunaan perpustakaan terhadap minat belajar dengan taraf signifikan yang ditentukan adalah $=0.05$. Berdasarkan hasil pengolahan SPSS versi 23 pada dua variabel yaitu penggunaan perpustakaan dan minat belajar pada kolom kedua Unstandarized Residual diperoleh nilai Kolmogorov-Smirnov $Z$ sebesar 0.200 dengan demikian dapat disimpulkan bahwa data penggunaan perpustakaan sekolah dan minat belajar peserta didik kelas VIII di SMPN 3 Minasate'ne Pangkep berdistribusi normal karena sig. lebih besar dari sig. yang sudah ditetapkan $(0.200>0.05)$.

\section{b. Uji Leniaritas}

Linearitas adalah sifat hubungan antara dua variabel. Uji linearitas bertujuan untuk mengetahui apakah dua variabel yaitu minat belajar (Y) terhadap penggunaan perpustakaan $(\mathrm{X})$ mempunyai hubungan yang linear secara signifikan atau tidak. Uji ini biasanya digunakan sebagai prasyarat dalam analisis korelasi ataupun regresi linear. Uji linearitas pada penelitian ini dilakukan dengan menggunakan program SPSS versi 23. Hasil analisisnya dapat dilihat pada tabel berikut ini:

Tabel 4.6

\section{Hasil Uji Linearitas}

\begin{tabular}{|l|l|l|l|}
\hline \multicolumn{1}{|c|}{ Variabel } & \multicolumn{1}{|c|}{ F } & \multicolumn{1}{|c|}{ Sig. } & \multicolumn{1}{c|}{ Keterangan } \\
\hline $\mathrm{XY}$ & 2.40 & 0.056 & Linear \\
\hline
\end{tabular}

Berdasarkan hasil uji linearitas di atas, diketahui bahwa nilai sig. Deviation from Linearity sebesar 0.056 karena nilai sig. $0.056>0.05$, sehingga disimpulkan bahwa penggunaan perpustakaan dengan minat belajar berupa garis linear. 


\section{c. Uji Hipotesis}

Berdasarkan uji prasyarat analisis statistik, diperoleh bahwa data pada penelitian ini berdistribusi normal dan bersifat linear. Oleh karena itu, pengujian hipotesis dapat dilakukan dengan menggunakan uji regresi linear sederhana dengan tujuan melihat pengaruh yang signifikan variabel penggunaan perpustakaan sekolah terhadap minat belajar peserta didik. Adapun tabel hasil uji regrasi linear sederhana yaitu:

Tabel 4.7

Hasil Uji Regresi Linear Sederhana

\begin{tabular}{|l|c|c|c|}
\hline \multicolumn{1}{|c|}{ Variabel } & $\begin{array}{c}\text { Unstandardized } \\
\text { Coefficients }\end{array}$ & T & Keterangan \\
\hline Constant (a) & 24,36 & & \\
\cline { 1 - 2 } Penggunaan & 0,24 & \multirow{2}{*}{2,91} & Berpengaruh \\
Perpustakaan(X) (b) & & & \\
\hline
\end{tabular}

Dependent Variable: Minat Belajar(Y)

Dari tabel di atas, pada tabel variabel kolom constant a adalah 24,36 dan pada kolom b 0,24 sehingga persamaan regresinya: $\widehat{Y}=a+b x$ atau 24,36+ 0,24X. Dari hasil analisis didapatkan taraf nyata $(\alpha)$ dan nilai tabel sebesar 5\% Kemudian diperoleh hasil analisis $t_{\text {hitung }}=2,91$ sedangkan $t_{\text {tabel }}=1,684$ artinya nilai $t_{\text {hitung }}$ lebih besar dari nilai $t_{\text {tabel }}$ $\left(t_{\text {hitung }}>\mathrm{t}_{\text {tabel }}=2,91>1,684\right)$. Dengan demikian penggunaan perpustakaan skolah berpengaruh positif terhadap minat belajar peserta didik kelas VIII di SMPN 3 Minasate'ne Pangkep.

Tabel 4.8

Uji Signifikansi Persamaan Regresi

\begin{tabular}{|l|l|l|l|}
\hline \multicolumn{1}{|c|}{ Model } & \multicolumn{1}{|c|}{ F } & \multicolumn{1}{c|}{ Sig. } & \multicolumn{1}{c|}{ Keterangan } \\
\hline Regresi & 8.51 & 0.006 & Signifikan \\
\hline
\end{tabular}

a.Dependent Variable: Variabel Y ( minat belajar)

b.Predictors: (Constant), Variabel X (penggunaan perpustakaan)

Hipotesis Statistik:

$\mathrm{H}_{0}: \beta=0$ (regresi tidak berarti) 


\section{$\mathrm{H}_{1}: \beta \neq 0$ (regresi berarti)}

Uji signifikansi persamaan garis regresi diperoleh dari baris Regresi yaitu $\mathrm{F}_{\text {hitung }}=$ 8,51 sedangkan $F_{\text {tabel }}=4,10$ artinya nilai $F_{\text {hitung }}$ lebih besar dari nilai $F_{\text {tabel }}\left(F_{\text {hitung }}>F_{\text {tabel }}\right.$ $=8,51>4,10)$. dan $p$-value/Sig. $=0,006<0,05$ atau $\mathrm{H}_{1}$ diterima. Dengan demikian, regresi $\mathrm{Y}$ atas $\mathrm{X}$ adalah signifikan atau penggunaan perpustakaan sekolah berpengaruh terhadap minat belajar peserta didik kelas VIII di SMPN 3 Minasate'ne Pangkep.

\section{d. Uji Korelasi}

\section{Tabel 4.9}

Hasil Uji Korelasi

\begin{tabular}{|l|l|l|l|l|}
\hline \multicolumn{1}{|c|}{ Variabel } & \multicolumn{1}{|c|}{$\mathbf{R}$} & \multicolumn{1}{c|}{ R Squere } & \multicolumn{1}{c|}{ Sig. } & \multicolumn{1}{c|}{ Keterangan } \\
\hline $\mathrm{X}-\mathrm{Y}$ & 0,42 & 0,183 & 0,006 & Ada Korelasi \\
\hline
\end{tabular}

Untuk mengetahui besarnya nilai korelasi dan besarnya presentase pengaruh penggunaan perpustakaan sekolah terhadap minat belajar peserta didik kelas VIII di SMPN 3 Minasate'ne Pangkep, dapat dilihat pada nilai R Square pada table sebesar 0,183 yang artinya besarnya persentase pengaruh penggunaan perpustakaan sekolah terhadap minat belajar peserta didik adalah sebesar $18,3 \%$ sedangkan $81,7 \%$ dipengaruhi oleh variabel lain.

\section{B. Pembahasan}

\section{Penggunaan Perpustakaan Sekolah Peserta Didik Kelas VIII SMPN 3}

\section{Minasate'ne Pangkep}

Perpustakaan merupakan upaya untuk memelihara, meningkatkan efisensi serta efektifitas proses belajar mengajar. Perpustakaan yang telah terorganisir dengan baik dan sistemastis maka secara langsung maupun tidak langsung memberikan kemudahan dalam proses belajar mengajar di sekolah. Pada kenyataannya perpustakaan sekolah akan tampak bermanfaat apabila benar-benar memperlancar pecapaian tujuan proses pembelajaran di sekolah.

Berdasarkan hasil analisis data yang telah dilakukan peneliti terhadap penggunaan perpustakaan sekolah peserta didik kelas VIII di SMPN 3 Minasate'ne Pangkep dengan responden berjumlah 40 orang dengan menggunakan instrumen skala penggunaan perpustakaan yang terdiri dari 16 pernyataan, maka diperoleh nilai minimum dan nilai maximum dari analisis deksriptif yaitu 25 dan nilai 62 .

Sehingga dapat digambarkan bahwa terdapat 3 responden pada kategori rendah dengan persentase $7,5 \%$, dan 30 responden berada pada kategori sedang dengan nilai persentase $75 \%$, sedangkan 7 responden berada pada kategori tinggi dengan persentase 
17,5\%. Jadi, penggunaan perpustakaan sekolah peserta didik kelas VIII di SMPN 3 Minasate'ne Pangkep terletak pada kategori sedang dengan nilai rata-rata (mean) sebesar 47,38. Hal ini dilihat dari frekuensi terbanyak jumlah responden yang berada pada rentang nilai 39-55 sebanyak 30 responden dengan persentase $75 \%$ yang berarti perlu ditingkatkan.

Dalam penggunaan perpustakaan sekolah di SMPN 3 Minasate'ne Pangkep sebenarnya fungsi dan manfaat perpustakaan sekolah kurang terealisasikan, dilihat dari tanggapan responden. Dimana banyak responden yang kurang terbiasa mengunjungi perpustakaan untuk pembelajaran sehingga hasil penelitian yang diperoleh dari analisis deskriptif dan analisis inferensial didapatkan bahwa penggunaan perpustakaan sekolah di SMPN 3 Minasate'ne Pangkep berada pada kategori sedang.

\section{Minat Belajar Peserta Didik Kelas VIII SMPN 3 Minasate'ne Pangkep}

Minat belajar memiliki peran yang sangat penting dalam diri peserta didik dan dampak besar atas sikap dan perilaku tersebut. Minat belajar peserta didik dapat menjadi motivasi yang kuat untuk belajar. Peran minat pada proses pembelajaran adalah untuk memusatkan pikiran serta menghadirkan kegembiraan dalam usaha belajar seperti adanya kegairahan, rasa senang, menambah semangat belajar, membantu untuk tidak melupakan apa yang telah dipelajari dan membuat kepuasan tersendiri dalam diri peserta didik. Maka dari itu di sini peran guru sangat penting untuk menambah minat belajar peserta didik dengan cara memanfaatkan perpustakaan sekolah sebagai sarana untuk pembelajaran.

Berdasarkan hasil analisis data yang telah dilakukan peneliti terhadap minat belajar peserta didik kelas VIII di SMPN 3 Minasate'ne Pangkep dengan responden berjumlah 40 orang menggunakan instrumen skala minat belajar yang terdiri dari 12 pernyataan, maka diperoleh nilai minimum dan nilai maximum dari analisis deksriptif yaitu 20 dan nilai 46.

Sehingga dapat digambarkan bahwa terdapat 3 responden pada kategori rendah dengan persentase $7,5 \%$, dan 27 responden berada pada kategori sedang dengan nilai persentase $67,5 \%$, sedangkan 10 responden berada pada kategori tinggi dengan persentase 25\%. Jadi, penggunaan perpustakaan sekolah peserta didik kelas VIII di SMPN 3 Minasate'ne Pangkep terletak pada kategori sedang dengan nilai rata-rata (mean) sebesar 39,93. Hal ini dilihat dari frekuensi terbanyak jumlah responden yang berada pada rentang nilai 30-40 sebanyak 27 responden dengan persentase 67,5\% yang berarti hal ini perlu ditingkatkan.

Pada hasil analisis minat belajar peserta didik kelas VIII di SMPN 3 Minasate'ne Pangkep dapat dilihat faktor yang mempengaruhi minat belajar antara lain yaitu faktor ekternal seperti motivasi, keingintahuan, perhatian, rasa senang dan keinginan untuk belajar. Dimana faktor-faktor tersebut masih kurang karena dilihat dari tanggapan responden pada saat mengisi angket. Sehingga hasil penelitian yang diperoleh dari 
analisis deskriptif dan analisis inferensial didapatkan bahwa minat belajar peserta didik di SMPN 3 Minasate'ne Pangkep berada pada kategori sedang.

\section{Pengaruh Penggunaan Perpustakaan Sekolah terhadap Minat Belajar Peserta}

\section{Didik Kelas VIII di SMPN 3 Minasate'ne Pangkep}

Berdasarkan dari hasil analisis statistik inferensial pengujian hipotesis yang telah dilakukan menunjukan bahwa nilai $(\mathrm{t})$ yang diperoleh dari hasil perhitungan $t_{\text {hitung }}$ didapatkan hasilnya lebih besar daripada nilai $(\mathrm{t})$ yang diperoleh dari $\mathrm{t}_{\text {tabel }}$ hasil distribusi $\left(\mathrm{t}_{\text {tabel }}\right)$. Dari hasil analisis didapatkan taraf nyata $(\alpha)$ dan nilai tabel sebesar 5\% Dimana telah diperoleh hasil analisis thitung $=2,91$ sedangkan nilai tabel $=1,684$ untuk 40 sampel yang dapat diartikan bahwa $t_{\text {hitung }}>t_{\text {tabel }}$ yaitu $2,91>1,684$. yakni $18,3 \%$ sedangkan sisanya sebesar $81,7 \%$ dipengaruhi oleh variabel lain. Maka dapat dilihat bahwa dari hasil penelitian yang dilakukan ini ternyata terdapat pengaruh antara penggunaan perpustakaan sekolah terhadap minat belajar pesertaa didik kelas VIII di SMPN 3 Minasate'ne Pangkep.

\section{SIMPULAN}

Penggunan perpustakaan sekolah berada pada ketegori sedang, dengan hasil persentase $75 \%$. Sedangkan minat belajar peserta didik kelas VIII di SMPN 3 Minasate'ne Pangkep juga berada pada kategori sedang dengan hasil persentase $67.5 \%$. Terdapat pengaruh penggunaan perpustakaan sekolah terhadap minat belajar peserta didik kelas VIII di SMPN 3 Minasate'ne Pangkep yang dilihat dari nilai (t) dimana diperoleh hasil perhitungan $t_{\text {hitung }}$ didapatkan hasilnya lebih besar daripada nilai $(t)$ yang diperoleh dari tabel hasil distribusi ( $\left.\mathrm{t}_{\text {tabel }}\right)$. Maka dengan demikian pengaruh penggunaan perpustakaan sekolah berpengaruh positif terhadap minat belajar peserta didik kelas VIII di SMPN 3 Minasate'ne Pangkep yakni 18,3\% sedangkan sisanya sebesar 81,7\% dipengaruhi oleh variabel lain.

\section{DAFTAR PUSTAKA}

Arikunto, Suharsimi. Prosedur Penelitian Suatu pendekatan Praktik. Jakarta: Rineka Cipta, 2006.

Aziz, Safrudin. Perpustakaan Ramah Difabel: Mengelola Layanan Informasi bagi Pemustidakaan Difabel. Depok: Ar-Ruzz Media, 2014.

Bafadal, Ibrahim. Pengelolaan Perpustakaan Sekolah. Cet. X; Jakarta: Bumi Aksara, 2015.

Darmanto, Priyono. Manajemen Perpustakaan. Jakarta: Bumi. Aksara, 2018.

Djali. Psikologi Pendidikan. Cet. X; Jakarta: Bumi Aksara. 2017. 
Darmadi. Pengembangan Model Metode Pembelajaran dalam Dinamika Belajar Siswa. Yogyakarta: Budi Utama, 2017.

Mangnga, Alias. Peranan Perpustakaan Sekolah Terhadap Proses Belajar Mengajar di Sekolah. Jupiter 14. no.1 (Maret 2015): h. 38-42.

Nur, Jumaidi. Pengaruh Sarana Belajar Terhadap Minat Belajar Siswa Kelas VII SMP Negeri 4 Tenggarong. Jurnal Cemerlang 3, no. 1 (Juni 2015): h. 3-15.

Prapanca, Minat Siswa Kelas IX terhadap Mata Pelajaran Tata Boga di SMA Negeri 1 Temon, Skripsi, Yogyakarta: Fakultas Teknik Universitas Negeri Yogyakarta, 2012.

Peraturan Pemerintah Republik Indonesia Nomor 24 Tahun 2014 Tentang Pelaksanaan Undang-Undang Nomr 43 Tahun 2007 tentang Perpustakaan. Jakarta, 2015.

Rifal, Agus. Perpustakaan Islam. Depok: PT. Raja grafindo Persada, 2014.

Rubianti, Pengaruh Kemandiria, Fasilitas dan minat Belajar trhadap Prestasi Belajar Sosiologi, Jurnal Ideguru 2, No. 1 (Mei, 2017): h. 11-24

Shaleh, Abdul Rahman. Pendidikan Agama dan Pembangunan Watidak Bangsa. Jakarta: PT Raja Grafindo Persada, 2005.

Sutrisno. Meningkatkan Minat dan Hasil Belajar TIK. Malang: Ahlimedia, 2021.

Syahputra, Edy. Snowball Throwing Tingkatkan Minat dan Hasil Belajar. Suka Bumi: Haura Publishing, 2020.

Zain, Aswan. Strategi Belajar Mengajar. Jakarta: Rineka Cipta, 2008. 